\title{
Developing Factors of E-Wom: Intention to Buy from the Consumer via Tik-Tok
}

\author{
Ratna Dewi \\ Department of Management, Faculty of Economic and Business, Universitas Muslim Indonesia, \\ Makassar City, Indonesia \\ Email address: \\ ratna.dewi@umi.ac.id
}

\begin{abstract}
This research focuses on developing new concepts and empirically testing eWoM variable-forming factors on consumer purchasing intentions, and looking at the indirect influence of e-wom forming indicators. This study used a sample of 100 respondents who had purchased after seeing tik-tok. The sampling technique used is purposive sampling by spreading questioner online. This study also uses structural equation technique with data analysis using SEM-PLS. The results showed that Platform Assistance has a significant effect on purchase intention. Not only that, but the concern of others and also helping the company has a positive and significant influence on purchasing intentions. This study is still rare in looking at what factors form the variable e-whom and how these factors influence consumer purchasing intentions. This research in the design is static, a model that develops based on empirical studies and testing that is only limited to establishing a simple relationship related to e-wom forming factors that can affect consumer purchasing intentions through a tik-tok application.
\end{abstract}

Keywords: e-WoM; Purchase Intention; Tik-Tok; Millennials.

Abstrak: Penelitian ini berfokus pada pengembangan konsep baru dan pengujian empiris faktor pembentuk variabel eWoM terhadap niat beli konsumen, serta melihat pengaruh tidak langsung indikator pembentuk e-wom. Penelitian ini menggunakan sampel sebanyak 100 responden yang melakukan pembelian setelah melihat tik-tok. Teknik pengambilan sampel yang digunakan adalah purposive sampling dengan menyebarkan kuesioner secara online. Penelitian ini juga menggunakan teknik persamaan struktural dengan analisis datanya menggunakan SEM-PLS. Hasil penelitian menunjukkan bahwa Bantuan Platform berpengaruh signifikan terhadap niat beli. Tidak hanya itu, kepedulian orang lain dan juga membantu perusahaan memiliki pengaruh yang positif dan signifikan terhadap niat beli. Penelitian ini masih jarang dalam melihat faktor-faktor apa saja yang membentuk variabel e-who dan bagaimana faktor-faktor tersebut mempengaruhi niat beli konsumen. Penelitian yang di desain ini bersifat statis, model yang dikembangkan berdasarkan studi empiris dan pengujian yang hanya sebatas menjalin hubungan sederhana terkait faktor pembentuk ewom yang dapat mempengaruhi niat beli konsumen melalui aplikasi tik-tok.

Kata Kunci: e-WoM; Niat Membeli; Tik-Tok; Milenial. 


\section{INTRODUCTION}

Millennials currently take an important role in various fields of technology, and these developments are driving Internet users to increase each year, enhanced by the data from the Indonesian Internet Services Provider Association (APJII). The second quarter of 2020 survey showed that the Internet in Indonesia was 196.7 million by the second period of 2020. Because if 171,2 million people were on the Internet in Indonesia in 2018. And the population of Indonesia reaches 266 million people, based on data from the Central Bureau of Statistics (BPS). Based on that, internet users in Indonesia reached 73.7 percent. The figure rises if compared to 2018 then only 64.8 percent.

Today, word of mouth marketing is well-known. Since centuries before the marketing science has evolved as it is now, this type of promotion was recognized. If a person (customer) is comfortable to purchase or utilize services or products somewhere, he likes to tell others, in particular the people closest to him, about his perceptions. Not only is this personal communication channel an effective promotional approach because it can be a company publicity, but it also costs no great deal because satisfied clients will facilitate the distribution of references or references to the products of the company to other consumers. WOM changed its name to e-WOM during the era of digitalisation, which today is (electronic word of mouth). This new Consumers ' online form has also played a significant role in the development of consumer behaviour. Recommendations or reviews made by other consumers, such as the joint review platform or community, could influence the consumer's purchasing interests (Jalilvand and Samiei, 2012).

SNS based on research by (Dick Stroud, 2008), has at least 5 basic functions: Includes: First; a profile which may include photos, videos and sounds. A profile is the user's own profile page. It can be private (for individuals) and public (available to everyone or search engines). The second then; network of contacts. Users can choose with whom they are interested. Third: Most social network members generally use e-mail rather than messaging applications. Fourth, sharing of content. Users can share messages, photos, music and videos on social media networks. The last one then; Content Added Value. The partnership relationship between SNS and content providers will increase user profiles.

It is known that the results of the "We Are Social" survey that currently active users of social media as many as 160 million, this number increased by 12 million ( 8.1 percent) from April 2019 to January 2020. Where the use of social media that was originally only to connect with others through software in a virtual community is limited, but now social media,both in the form of blogs, microblogging,networks sosial and various media services are then used with various fungi by its users in various formsof work. In 2020 TikTok became one of the most popular apps in Indonesia (Linlin et al., 2020), this application is not a new application in Indonesia because in 2018 to 2019 this application was already known by the public, but at that time TikTok was considered to be a fooling application because, had been blocked by the government after many negative reports that emerged from the public.

Thus, in 2018, TikTok was officially blocked in Indonea by the Ministry of Communications and Information Technology. However, this blocking is only temporary because of the Covid-19 pandemic, in which everyone is forced not to carry out external activities to prevent virus transmission. TikTok is considered to be able to dispel boredom because this app presents a variety of interesting features for its users (Jacobsen, 2018). This 
application allows users to create videos which are only approximately $30 \mathrm{sec}$. in order to produce a special, unique and interesting effect and support a lot of music so that users can perform in a wide range of styles or dances and many more to promote creativeness for their users (Linlin et al., 2020).

In the world of online marketing, TikTok has great interests and content spreads to every social media platform. The rise in the number of internet users also influences the behavior of people to purchase items (Madeeha et al., 2020). If we wanted to purchase a product in the past, then before an agreement was concluded, we had to meet or discuss things with the buyers and the sellers (Choi, 2019).

Dissemination to other consumers of information on an individual's experience with a product. The Word of the Mouth is a form of communication (E-WOM). According to (Nick, 2019) Word of Mouth (E-WOM) is the behavior of the consumer in providing brand or product information to others (included). Next, (Ahmad et al., 2020) said that phenomenom is not only word of mouth communication, but has spread to the electronic world known as the Eletronik Word of Mouth (E-WOM). According to (Kang and Hustvedt, 2014) that E-WOM is a positive and negative demand formed from the opinion of consumers, prospective consumers or former consumers of a product that is widely accessible in cyberspace (M.K., K.O., and Neil, 2008). The application of E-WOM on social media is considered more effective because it can be reached by the wider community including millennials. The low cost and high impact of the process can benefit from the application of e-wom to media companies (Tan and Chang, 2015). As consumers develop an attitude, the opinion of others through an experience will convince others (Shahab et al., 2020).

Social networks also help companies to respond directly to customer complaints and customer dissatisfaction (such as the star rating system in the Shopee application). Edevelopment WOM's is also due to the reading, even commentary on the proportion of other information seekers regarding the particular product by consumers writing on a product posted via Internet or social media (Ahmad et al., 2020). The good reviewer of a product on the Internet than,it will be great for purchasers (Tan and Chang, 2015). In this study we used variable-forming factors of e-WoM on purchase intention. The reason is because today it is a significant aspect of consumer information, in particular for the users in digital information for buying a product.

\section{THEORITICAL REVIEW}

Electronic word of mouth. Advances in technology, especially in WWW (Word Wide Web) internet network, enable the existence of a Word of Mouth communication which is not just a form of individual communication but can be a word of mouth communication through on-line media. Due to their degree of accessibility and broader reach, Eletronic Word of Mouth became a very important place for consumers to give their opinions and to consider it more effective than Word of Mouth. (Jalilvand, 2012). E-wom becomes a very attractive concept for consumers to give their opinions on their e-commerce shopping experience and is seen as having a broader access and reach for people (Andreassen and Streukens, 2009).

Social media is one of the innovative methods for companies in order to sell products or services; the approach adopted using E-existence WOM's is a positive or negative statement of products or companies provided to many people and institutions via the internet 
by clients of pontencially companies (López et al., 2016). E-WOM could indeed, incredibly, provide a variety of means in which a person can influence the purchase of certain products or services. The media used can be limitless on e-mails, videos, social media accounts and internet forums.

(Jasen, 2009) mention that one of the new forms of marketing potentially the onset of E-WOM is microblogging using social communication Web services such as Twitter Instagram, Path. In this attention economy, microblogging is a new form of communication where users can describe interesting things and express an attitude that they are willing to share with others in a short post (i.e., microblogs). Furthermore, it is explained by (Jacobsen, 2018), that Electronic Word of Mouth is a social communication in the Internet where Web browsers send each other and receive information related to products online.

E-WOM functioned as one way of marketing so that consumers can immediately understand a product or brand. The information that consumers get is an opinion from otherconsumers, be it face-to-face or through online media. Research conducted by (Jeong and Jang, 2011) confirms that the Electronic Word of Mouth (E-WOM) positively reflected through three dimensions, namely: Concern for Others, Expressing Positive Feelings, and Helping the Company. But on the other hand, research conducted by Hennig-Thaurau et al., (2004) reflects the Electronic Word of Mouth (E-WOM) through 8 dimensions, namely: (1) Platform Assistance, (2) Venting Negative Feelings, (3) Concern for Others, (4) Extraversion/Positive Self-Enchancement, (5) Social Benefits, (6) Economic Incentives, (7) Helping the Company, and (8) Advice Seeking.

This study uses five dimensions because the dimensions are considered relevant to the research to be conducted. Venting Negative Feelings dimensions are not used because research focuses on positive Word of Mouth electronics. Extravension/Positive SelfEnchancement in general has similarities with the dimensions of Expressing Positive Feelings, so this study only chose one of them. This study also does not use the dimension of Advice Seeking with the reason because the Word of Mouth Electronic Research in question is a spontaneous Word of Mouth Electronic, not An Electronic Word of Mouth that respondents want to know in advance. And this study also does not use the social benefits dimension because the indicators in the Social Benefits dimension talk a lot about the advantages of social media use. So in conclusion, this study only uses five dimensions namely, Platform Assistance, Concern for Others, Expressing Positive Feelings, Economic Incentives, and Helping the Company.

Concern Fof Others. According to (Henning, 2004), caring for others is closely related to alturism. For example, preventing someone from buying a bad product. There are several ways companies join other companies to improve their position in economic competition, one of which is concern. These methods are taken by a company so that the company can be the first among its competitors. In addition, the company can also expand its business and get a lot of capital.

Expressing Positive Feelings. Expressing these positive feelings is triggered by a positive consumption experience. A consumer's positive experience of a product makes it a contribution to share the experience with others. In contrast to the motive to express negative feelings, expressing these positive feelings is triggered by the experience of positive 
consumption. The positive experience of restaurant customers contributes to psychological tension in customers because they have a strong desire to share the joy of other people's experiences. This tension can be informed by articulating a positive experience.

Helping the Company. Helping the company is the result of consumer satisfaction with a product, and the next desire to help the company. Where customers are motivated to engage in E-WOM communications to provide companies with "rewards" based on their good experience. The effect is that the company will be or remain successful. The background to this motivation is the same as the motive of caring for others, altruism or a sincere desire to help others. The only difference between helping the company and caring for others is the object. In thurau et al research, restaurant customers are motivated to engage in eWOM because it provides something company in return for a positive experience of their dining. Helping the company is the result of customer satisfaction with the product and subsequent desire to help the company. Customers are motivated to engage in eWOM communication to give the company something in return based on a good experience

Platform Assistance. Platform assistance or assistance provider that is the frequency of consumers in their visits and write their opinions or in other words Operationalize eWOM behavior can be based on two ways, namely by looking at the frequency of consumer visits on the opinion platform and the number of comments written by consumers on the opinion platform.

Economic Incentives. Economic incentives are the curiosity of a person to obtain incentives from thecompany, Further Economic benefits have been designated as an important driver of human behavior in general and are considered by the recipient as a token of appreciation to the recipient by the gift giver. Thus the receipt of economic awards for eWOM communication from platform operators is another form of utility acceptance.

E-Wom and Purchase Intention. There is basically a difference between WOM and EWOM where it can be distinguished based on the media used; traditional WOM usage is usually face-to-face. While the use of EWOM is usually online through cyberspace. As technology advances, the physical place where word of mouth occurs has changedfrom faceto-face to cyber-space. In this study, the authors used eWoM on the grounds that word of mouth electronic is currently an important part of Instagram users in digging for information about a product to be purchased.

Although eWoM among customers plays an important role in modern business situations. We recognize that there is little difference in terms of importance between online and offline consumers (M.K. et al., 2008). Online customers do not come face-to-face with vendors, word of mouth is more important to online consumers than offline consumers (Tan and Chang, 2015). eWOM has focused on the requested communication between individuals with strong and weak ties, friends or individuals outside one's respective social circles (Shahab et al., 2020).

eWoM can also take many forms, including online reviews, private messages, or blog posts (Wang et al., 2019) where at least one party is interested and actively seeking productrelated information. However, this study does not take into account for unsolicited eWOM and can be found on Instagram by individuals who may not even be interested in the brand 
in question (Ahmad et al., 2020), but are related to the brand's communication exchange that is 'connected' with members of the brand community. As a result, eWOM research does not adequately address the diffusion of existing information associated with very weak or non-existent social ties in this context. Where, community members can engage in eWOM both inside and outside the community (López et al., 2016), but little is known about whether their eWOM behavior is related or unrelated to their engagement behavior with the community of a product (Andreassen and Streukens, 2009).

In the context of trading on social media, the purchase intention refers to the consumer's intention to engage in online purchases from electronic vendors on social trading sites. Intention has proven to be a valid predictor of actual behavior (Gefen and Straub, 2004). Since actual behavior is usually difficult to measure, it is very common to measure behavioral intentions in lieu of some actual behavior (Kusumasondjaja and Tjiptono, 2019). Based on this point, the purchase intention can be considered as a reflection of the results of consumer behavior or it can be said that consumers get information from other consumers about a product. It is clear that the purchase can be considered the final decision in most transactions. At the same time, many previous studies on electronic word of mouth in the context of consumer buying intentions. (Liu et al., 2019) considers that the purchase intention in response in the eWoM model (Liu et al., 2019), because, they think it can reflect the results and consumer choice (Choi, 2019). Therefore, in this case, the buying intention in social trading will still be treated in response to the eWoM effect. This represents the consumer's final decision based on the trust of buying a product.

H1: Platform Assistance is positive and significant to millennials' purchase intention

H2: Concern for Others is positive and significant to millennials' purchase intention

H3: Expressing Positive Feelings are positive and significant to millennials' purchase intention

H4: Economic Incentives are positive and significant to millennials' purchase intention

H5: Helping the Company is positive and significant to millennials' purchase intention

\section{METHODS}

The study included customers who purchased the product on the basis of the content on the tik-tok app. The number of users making transactions in Tik-tok media has so far been inaccurate. The sampling method used in this study was thus a category that was not likely, with 100 respondents. Consumers that bought products are the criteria in this study as they see the social media content of Tik-tok and the sampling method used for this study is a purposive sampling.

We asked respondents to demonstrate their response to the products they bought on the model . based of the content they saw on the Tik-tok app using a five-point Likert scale. The scale used by (1) is highly divisive; (2) is divisive; (3) is simple; (4) is divisible; and (5) is divided by an agreed. The criteria of this sample are that the product is purchased because the content of Tik-tok is visible. Based on the fact that the transaction was at least 2 times done, respondents had sufficient experience with e-WoM compared to respondents who only purchased for the first time, thus making it easier to obtain reliable research findings for researchers. 
Structural equation modeling techniques (SEM) (Albright et al., 2009), which was used to empirically test the factors for e-WoM and their effect on consumer purchasing intentions throughout this research. This study uses PLS according to (Sarstedt et al., 2011), this study estimates Alpha Cronbach (CA), total correlation items, and contemplatory factor analysis to test reliability, convergent validity and discriminant validity for each concept framework construct (Jöreskog, 2005). Moreover, the testing of the hypotheses is carried out on the basis of internal tests of the model, including r-square results, coefficient parameters and $t$ statistics. To determine that the value of significance amongst contracts, $t-$ statistics, and p-values can be agreed or rejected, among other things. The test was performed by SmartPLS (Partial Least Square) 3.0. This research hypothesis was used. The bootstrapping results show these values. The thumb rules used in the study were 1,96 tstatistics, with a p-value of 0,05 (5 percent) and a positive beta coefficient.

\section{RESULTS}

Because this study is devoted to millennials or Gen Y, this study relates to individuals born in 1982-2004 as according (Linlin et al., 2020), that the millennial group as consisting of individuals born between 1982-2004. From the table, the age of respondents 18-20 years as many as 34 people or 34\%, then the age of 21-25 years as many as 64 people or $64 \%$ and 26-30 years only 1 person or $1 \%$. Thus it can be concluded that the majority of TikTok app users are mostly aged 21-25 years. Whereas, As many as 23 men or $23 \%$ and women 77 people or $77 \%$ in other words, Respondents to this study were dominated by women.

Table 1. Respondent data

\begin{tabular}{ccc}
\hline Gender & $\mathbf{N}$ & $\mathbf{\%}$ \\
\hline Male & 23 & $23 \%$ \\
Female & 77 & $77 \%$ \\
\hline Age & $\mathbf{N}$ & $\mathbf{\%}$ \\
\hline $18-20$ years old & 34 & $34 \%$ \\
$21-25$ years old & 65 & $65 \%$ \\
$26-30$ years old & 1 & $1 \%$ \\
\hline
\end{tabular}

Based on the table 2, it is known that each indicator on the research variable has the largest Croos Loading value on the variable itformed, compared to the value of Croos Loading on other variables. Based on the value of Croos Loading that has been obtained, it can be stated that the indicators used in this study have a good Discriminant Validity in compiling the variables.

In addition, the results of discriminat validity can also be known through other methods, namely by looking at the Average Variant Extracted (AVE) value which each indicator should be $>0.5$ for a good model. From the table 3, it is known that the AVE value of each variable is more than 0.5 thus it can be stated that each variable has a good Discriminant Validity value. 
Table 2. Cross Loading

\begin{tabular}{lllllll}
\hline & Pa & Cfo & Epf & Ei & Htc & Mb \\
\hline PA1 & 0.878 & 0.696 & 0.707 & 0.667 & 0.537 & 0.674 \\
PA2 & 0.891 & 0.685 & 0.764 & 0.639 & 0.529 & 0.702 \\
PA3 & 0.905 & 0.821 & 0.857 & 0.748 & 0.568 & 0.807 \\
CFO2 & 0.759 & 0.927 & 0.774 & 0.774 & 0.607 & 0.796 \\
CFO3 & 0.771 & 0.920 & 0.839 & 0.743 & 0.583 & 0.763 \\
EPF1 & 0.812 & 0.804 & 0.948 & 0.760 & 0.583 & 0.762 \\
EPF2 & 0.854 & 0.854 & 0.956 & 0.821 & 0.620 & 0.826 \\
EI1 & 0.722 & 0.765 & 0.793 & 0.864 & 0.575 & 0.712 \\
EI2 & 0.558 & 0.649 & 0.640 & 0.841 & 0.628 & 0.654 \\
EI3 & 0.702 & 0.698 & 0.706 & 0.872 & 0.697 & 0.699 \\
HTC1 & 0.589 & 0.587 & 0.553 & 0.675 & 0.918 & 0.714 \\
HTC2 & 0.562 & 0.609 & 0.639 & 0.663 & 0.832 & 0.669 \\
HTC3 & 0.381 & 0.423 & 0.394 & 0.519 & 0.786 & 0.545 \\
MB1 & 0.759 & 0.782 & 0.742 & 0.783 & 0.766 & 0.884 \\
MB2 & 0.739 & 0.751 & 0.764 & 0.733 & 0.730 & 0.938 \\
MB3 & 0.684 & 0.726 & 0.715 & 0.664 & 0.634 & 0.902 \\
MB4 & 0.789 & 0.766 & 0.791 & 0.730 & 0.702 & 0.930 \\
MB5 & 0.764 & 0.818 & 0.792 & 0.739 & 0.645 & 0.903 \\
\hline
\end{tabular}

Table 3. Average Variant Extracted (AVE)

\begin{tabular}{cc}
\hline Variable & Ave \\
\hline (Platfrom Assistance) & 0.794 \\
(Concern for Others) & 0.812 \\
(Expressing Positive Felling) & 0.850 \\
(Economic Incentives) & 0.738 \\
(Helping Company) & 0.717 \\
(Purchase Intention) & 0.831 \\
\hline
\end{tabular}

Furthermore, the researchers went to the Reliability test stage, where this test aims to measure the reliability of a questionnaire or consistency of respondents' answers regarding certain variables. The Reliability Test is conducted by measuring the correlation between question answers. A variable is compressed reliably if the Composite Reliability value is 0.70 .

From the table 4, the output in Composite Rehab indicates that on each variable there is no less than 0.70 and is declared eligible for Composite Rehabilitation. So it can be concluded that the whole variable has a high level of reliability. This Reliability Test can also be amplified by using the Cronbanch Alpha value. A variable if it has a Cronbach Alpha value of 0.7. The table above also shows the value of Cronbanch Alpha and it can be known that the research variable qualifies as Cronbanch Alpha value because the variable has a value of $>0.7$ and has a high level of Realibility. 
Table 4. Composite Reliability and Cronbanch Alpha

\begin{tabular}{ccccc}
\hline Variable & Cronbanc'h Alpha & rho_A & Composite Rehab & (AVE) \\
\hline $\mathrm{Pa}$ & 0.871 & 0.879 & 0.921 & 0.794 \\
$\mathrm{Cfo}$ & 0.844 & 0.888 & 0.928 & 0.812 \\
$\mathrm{Epf}$ & 0.911 & 0.917 & 0.944 & 0.850 \\
$\mathrm{Ei}$ & 0.823 & 0.824 & 0.894 & 0.738 \\
$\mathrm{Htc}$ & 0.802 & 0.819 & 0.884 & 0.717 \\
$\mathrm{Mb}$ & 0.949 & 0.950 & 0.961 & 0.831 \\
\hline
\end{tabular}

Then furthermore conducted inner model testing (StructuralModel) where this test is a model that describes the relationship between latent variables evaluated using R2, RSquare value is the coefficient of determination in endogenous constructs. According to (Hair et al., 2016), said that 0.75 (strong), 0.5 (strong), 0.25 (weak). Values that show how much the value of independent variables influence where in this study are Platform Assistance, Concern for Others, Expressing Positive Feelings, Economic Incentives, and Helping the Company to Buy Interests.

Table 5. R Square Testing

\begin{tabular}{ccc}
\hline Variable & R Square & Adjusted R Square \\
\hline Purchase Intention & 0.816 & 0.806 \\
\hline
\end{tabular}

Based on table 5, results it is known that the variable purchase intention is influenced by 81.6 percent by the electronic word of mouth forming factors namely; Platform Assistance, Concern for Others, Expressing Positive Feelings, EconomicIncentives, and Helping the Company. In other words, the remaining 81.6 percent was 18.4 percent likely influenced by other forming factors that researchers did not input in the study. 


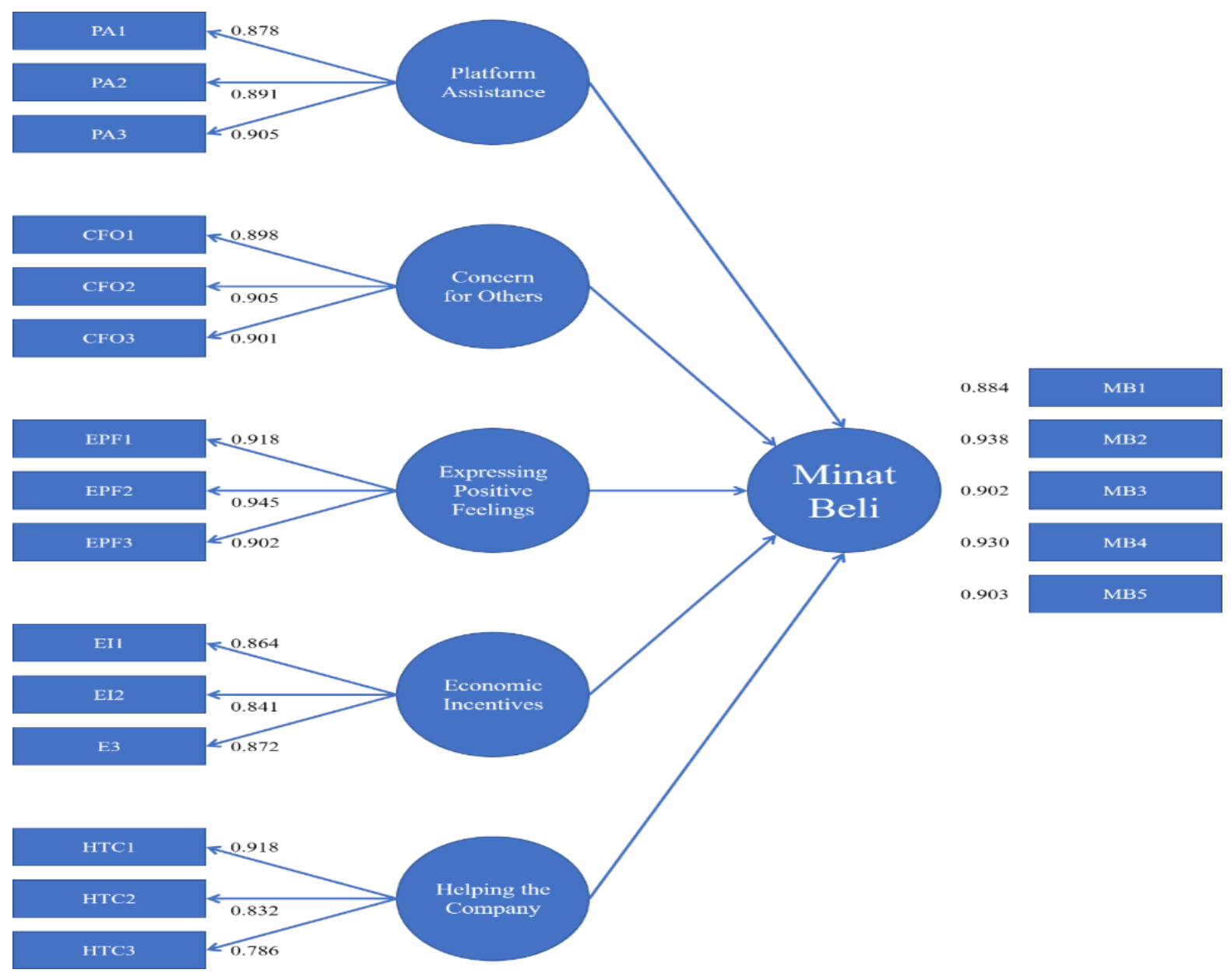

Figure 1. Hypothesis Testing

The value to point to the direction of the variable relationship is whether the hypothesis studied has a positive or negative direction. Looking at the Path Coefficient value that has a range of values above 0 and below one is declared positive.

Table 6. Path Coefficient

\begin{tabular}{cc}
\hline Variable & Purchase Intention \\
\hline $\mathrm{Pa}$ & 0.220 \\
$\mathrm{Cfo}$ & 0.297 \\
$\mathrm{Epf}$ & 0.179 \\
$\mathrm{Ei}$ & 0.003 \\
$\mathrm{Htc}$ & 0.325
\end{tabular}

Based on the table 6, point out that the whole model has a Coefficient Path value with a positive number. This indicates that the greater the coefficient path value of an independent variable against a dependent variable, the stronger the influence between exogenous variables on those endogenous variables. Then, based on the results of the data 
conducted, the results can be used to answer hypotheses in this study. The hypothesis test in this study was conducted by looking at the value in T-Statistic $>1.9$ and the value in PValues $<0.05$. the following are the hypothetical test results that have been obtained through the Inner Model:

Table 7. T-Statistic and P-Values

\begin{tabular}{lllllc}
\hline \multicolumn{1}{c}{ Variables } & \multicolumn{1}{c}{$\begin{array}{c}\text { Original } \\
\text { Sample (O) }\end{array}$} & $\begin{array}{c}\text { Mean Sample } \\
(\mathbf{M})\end{array}$ & (STIDEV) & $\begin{array}{c}\text { T } \\
\text { Statistic }\end{array}$ & $\begin{array}{c}\text { P } \\
\text { Value }\end{array}$ \\
\hline $\begin{array}{l}\text { Platfrom Assistance-> Purchase } \\
\text { Intention }\end{array}$ & 0.220 & 0.217 & 0.077 & 2.852 & 0.005 \\
$\begin{array}{l}\text { Concern of Others -> Purchase } \\
\text { Intention }\end{array}$ & 0.297 & 0.309 & 0.112 & 2.653 & 0.008 \\
$\begin{array}{l}\text { Expressing Positive Feelings -> } \\
\text { Purchase Intention }\end{array}$ & 0.175 & 0.170 & 0.105 & 1.675 & 0.095 \\
$\begin{array}{l}\text { Economic Incentives-> } \\
\text { Purchase Intention }\end{array}$ & 0.003 & -0.005 & 0.104 & 0.032 & 0.975 \\
$\begin{array}{l}\text { Helping the Company-> } \\
\text { Purchase Intention }\end{array}$ & 0.325 & 0.329 & 0.065 & 4.968 & 0.000 \\
\hline
\end{tabular}

On that table 7 , it can be known that only three variables that have a positive and significant effect on buying interest and the other two variables do not have a positive and significant effect. First Platfrom Assistance which has a T-Statistical value of 2,852 which means that platfrom assistance has a significant influence on millennials' buying interest in TikTok application and the value of P-Value 0.005 which means that Platfrom Assistance positively influences millennials' buying interest in TikTok application. Then the second, Concern of Others where the result has a T-Statistical value of 2,653 which means the concern of outher also has a significant effect on the buying interest of millennials on tiktok application with a value of P-Value 0.008 which means Concern Of Outhers positively affects the buying interest of millennials on tikTok application. Third, Expressing Positive Feelings has a T-Statistic value of 1,675, meaning expressing positive feelings has no significant effect on millennials' buying interest in tiktok application and the value of PValue is 0. 095. Furthermore, economic incentives this variable has a T-Statistical value of 0.032 which also has no significant effect on the buying interest of millennials with a value at P-Value of .0 .975 . The last is Helping the Company where this variable has a TStatistical value of 4,968 and the P-Value value is 0.000 which means Helping the Company positively affects the buying interest of millennials on the TikTok application.

\section{DISCUSSION}

Platfrom Assistance and millennial buying interests. In the results of this study suggests that the variable Platfrom Assistance has a significant effect on purchase intention. So this study can prove the first hypothesis that says that "Platfrom Assistance has a positive and significant effect on millennials' buying interest in TikTok application.It also indicates that 
tikTok application users get a lot of information and recommendations about a product on the application. These results are consistent with research conducted by (Firman et al., 2016) that platfrom assistance has a significant effect on buying interest.

Concern for Others and millennial buying interests. This study can prove the second hypothesis accepted that "Concern for Others positively and significantly affects millennials' buying interests on TikTok applications". This certainly indicates that millennials who use TikTok application feel that other TikTok app users help them in finding the right product information. This is in line with the results of research conducted by (Ahmad et al., 2020) that concern for others has a significant influence on buying interest variables.

Expressing Positive Feelings and millennials' buying interests. On this variable, it has insignificant results or in other words this variable has not been able to be considered as a factor that can influence consumer buying interest. Thus this hypothesis does not support or be rejected. Respondents felt that their purchasing decisions did not depend on their positive feelings in looking at the products or content on tiktok. The results of this study are also the same as (López et al., 2016) where the variable Expressing Positive Feelings has not been able to provide significant results to consumer buying interests.

Economic Incentives and millennials' buying interests. In this study, variable Economic Incentives had insignificant results on buying interests. Thus the fourth hypothesis that states that "Economic Incentives have a positive and significant effect on millennials' buying interest in TikTok applications" cannot be supported or in other words this hypothesis is rejected. It is also pointed out that millennial TikTok app users are not focused on the incentives they can get from utilizing the app. Consumers are only interested in product reviews that are on the tik-tok application that can make them want to buy the product.

Helping the Company and millennial buying interests. Furthermore, Helping the Company has significant results against ask to buy. then this study can prove the fifth hypothesis that states that "Helping The Company has a positive and significant effect on millennials' buying interest in the tiktok application is accepted. This certainly indicates that millennial TikTok users are more likely to help local entrepreneurs by buying their products and give a good rating to the company through the TikTok application because the application helps them get information about a product. This research is certainly in line with the research conducted by (Tan and Chang, 2015) where the results of the study stated that consumers take into account their pisicological factors in viewing a content.

\section{CONCLUSION}

Firstly, This research is compiled with structured writing rules, but there are still some limitations experienced in the preparation. First, the taking of respondents is only limited to a few people inthe city of Makassar, so to generalize the results of the research also needed further research involving other cities as a whole. In this study is also still self-report using 
questionnaires. For the next study, it is expectedthat researchers can expand the variable shaper electronic word of mouth related to other purchase intentions to see the consistency of the results of this study, of course by expanding new variables or adding new variables in testing the research model.

Second, WOM and eWOM were measured with a one scale. The study could also take into consideration various dimensions (e.g. affective commitment and intensity) and different virtual channels (e.g. blogs, Facebook and websites). Thirdly, the dimensions of commitment were measured intentionally. While most service empirical studies are measured intention rather than behavior (Kim et al., 2015), substantial differences can exist. Future studies may make the distinction those and examine the effect on purchase intention or consumer behaviour.

Finally, the e-wom study must continue by identifying the emission and the receiver approach. The scope to which consumers consulting and making purchasing intention online recommendations are still more likely to get a response on their life experience should be analysed. Because, The decision-making method is a diversified phase in which customers with various decisions influence. In order to maximize their satisfaction level, perceptions and perspective, customers intend to obtain information on products and services.

\section{REFERENCE}

Ahmad, D., Ruaa, H., Tillal, E., Muhammad, R.-S. P., Dongmei, C., and Naphat, K. (2020, January 1). Factors affecting eWOM credibility, information adoption and purchase intention on Generation Y: a case from Thailand. Journal of Enterprise Information Management. https://doi.org/10.1108/JEIM-04-2019-0118.

Albright, Jeremy J.; Park, H.M. (2009). Albright, J. Indiana University. Retrieved from http://hdl.handle.net/2022/19736.

Andreassen, T. W., and Streukens, S. (2009). Service innovation and electronic word of mouth: Is it worth listening to? Managing Service Quality: An International Journal, 19(3), 249-265. https://doi.org/10.1108/09604520910955294.

Choi, Y. K. (2019). Characters' persuasion effects in advergaming: Role of brand trust, product involvement, and trust propensity. Internet Research, 29(2), 367-380. https://doi.org/10.1108/IntR-01-2018-0021.

Constantinides, E. (2014). 'Foundations of social media marketing', Procedia-Social and Behavioral Sciences, vol. 148, pp. 40-57.

Gefen, D., and Straub, D. W. (2004). Consumer trust in B2C e-Commerce and the importance of social presence: Experiments in e-Products and e-Services. Omega, 32(6), 407-424. https://doi.org/10.1016/j.omega.2004.01.006.

Hair Jr., J. F., Hult, G. T.M., Ringle, C., and Sarstedt, M. (2016). A primer on partial least squares structural equation modeling (PLS-SEM). Sage Publications Ltd.

Harrison-Walker, L.J. (2001). "The measurement of word-of-mouth communication and investigation of service quality and customer commitment as potential antecedents", Journal of Service Research, Vol. 4 No. 1, pp. 60-75.

Hennig-Thurau, T., Gwinner, K.P., Walsh, G. and Gremler, D.D. (2004). "Electronic wordof-mouth via consumer-opinion platforms: What motivates consumers to articulate themselves on the internet?", Journal of Interactive Marketing, Vol. 18 No. 1, pp. 3852 . 
Hua, N. (2016). "E-commerce performance in hospitality and tourism", International Journal of Contemporary Hospitality Management, Vol. 28 No. 9, pp. 2052-2079.

Jacobsen, S. (2018). Why did I buy this?: The effect of WOM and online reviews on post purchase attribution for product outcomes. Journal of Research in Interactive Marketing, 12(3), 370-395. https://doi.org/10.1108/JRIM-12-2017-0102

Kang, J., and Hustvedt, G. (2014). Building Trust Between Consumers and Corporations: The Role of Consumer Perceptions of Transparency and Social Responsibility. Journal of Business Ethics, 125(2), 253-265. https://doi.org/10.1007/s10551-0131916-7.

Kim, E.E.K. and Lee, C.H. (2015). "How do consumers process online hotel reviews? The effects of eWOM consensus and sequence", Journal of Hospitality and TourismTechnology, Vol. 6 No. 2, pp. 113-126.

Kusumasondjaja, S., and Tjiptono, F. (2019). Endorsement and visual complexity in food advertising on Instagram. Internet Research, 29(4), 659-687. https://doi.org/10.1108/IntR-11-2017-0459.

Linlin, Z., He, L., Feng-Kwei, W., Wu, H., and Zejin, T. (2020). How online reviews affect purchase intention: a new model based on the stimulus-organism-response (S-O-R) framework. Aslib Journal of Information Management. https://doi.org/10.1108/AJIM-11-2019-0308.

Liu, C., Bao, Z., and Zheng, C. (2019). Exploring consumers' purchase intention in social commerce: An empirical study based on trust, argument quality, and social presence. Asia Pacific Journal of Marketing and Logistics, 31(2), 378-397. https://doi.org/10.1108/APJML-05-2018-0170.

López, M., Sicilia, M., and Hidalgo-Alcázar, C. (2016). WOM Marketing in Social Media. Advertising in New Formats and Media,149-168. https://doi.org/10.1108/978-178560-313-620151007.

M.K., C.C., K.O., L.M., and Neil, R. (2008). The impact of electronic word-of-mouth: The adoption of online opinions in online customer communities. Internet Research, 18(3), 229-247. https://doi.org/10.1108/10662240810883290.

Madeeha, I., Shakil, A.M., and Farooq, M. O. (2020). Understanding consumers' trust in social media marketing environment. International Journal of Retail \& Distribution Management. https://doi.org/10.1108/IJRDM-07-2019-0225.

Nick, H. (2019). The impact of positive valence and negative valence on social commerce purchase intention. Information Technology \& People, 33(2), 774-791. https://doi.org/10.1108/ITP-02-2018-0099.

Sarstedt, M., Henseler, J., and Ringle, C.M. (2011). Multigroup analysis in partial least squares (PLS) path modeling: Alternative methods and empirical results. Advances in International Marketing, 22(June 2014), 195-218. https://doi.org/10.1108/S14747979(2011)0000022012.

Shahab, P., Tara, D., and J.L., C. W. (2020). Electronic word of mouth in tourism and hospitality consumer behaviour: state of the art. Tourism Review. https://doi.org/10.1108/TR-01-2019-0019.

Tan, W. K., and Chang, Y. G. (2015). Electronic-word-of-mouth performance in different psychological distances and familiarity. Online Information Review, 39(4), 449-465. https://doi.org/10.1108/OIR-10-2014-0255. 
Wang, C. and Kubickova, M. (2017). "The impact of engaged users on eWOM of hotel Facebook page", Journal of Hospitality and TourismTechnology, Vol. 8 No. 2, pp. 190-204.

Zhao, X., Sun, Y.S., Wang, L., Guo, X. and Law, R. (2015). "The influence of online reviews to online hotel booking intentions", International Journal of Contemporary Hospitality Management, Vol. 27 No. 6, pp. 1343-1364. 